\title{
FACTORS INFLUENCING NEST SITE SELECTION OF BALD EAGLES IN NORTHERN SASKATCHEWAN AND MANITOBA
}

\author{
by JONATHAN M. GERRARD, ${ }^{*}$ PETER GERRARD, ${ }^{* *}$ \\ WILLIAM J. MAHER $†$ \\ and DOUGLAS W. A. WHITFIELD $+\dagger$
}

In the course of 7 years' research on Bald Eagles in Northern Saskatchewan nd Manitoba, we gained some imressions about eagle nest sites. ${ }^{3}{ }^{13}$ In rder to test these observations, we eanalyzed our Bald Eagle data ollected from 1968 through 1974. Dur information is from extensive erial surveys of Bald Eagles in central askatchewan and Manitoba in $1969^{13}$ Ind a survey of central and northern askatchewan in 1974. Also, we have een studying the eagle population ince 1968 on Besnard Lake which is cated in central Saskatchewan in the Northern Coniferous forest of the recambrian shield about 40 miles vest-northwest of Lac La Ronge. ${ }^{11} 12$

METHODS. In 1974 our Bald Eagle

*954 - 15th Ave. Southeast,

Minneapolis, Minnesota. 55414

*43 Scotia St.,

Winnipeg, Manitoba.

tDepartment of Biology,

University of Saskatchewan,

Saskatoon, Saskatchewan.

S7N 0W0

tDepartment of Botany,

University of Alberta,

Edmonton, Alberta.

T6G 2E9 survey involved aerial censuses of shoreline in 20 randomly selected sample units of boreal forest. Between units we flew straight-line transects at 300 feet altitude; all eagle nests seen within 220 yards of the airplane were recorded. All 1974 data in this paper are from these transects. In analyzing the results of the transects, we considered all nests within 220 yards of a lake or river as being in shoreline habitat and all nests beyond that as being in inland habitat.

To understand the characteristics which make a shoreline attractive for a Bald Eagle to nest, we analyzed all nests visited in July, 1969, as to kind of tree it was in, whether it was on an island or near the edge of a lake or river, and whether it was on large or small lakes or rivers.

We arbitrarily considered all lakes with a total shoreline of 7 miles or more as large and all rivers delineated by two lines on 1:250,000 maps as

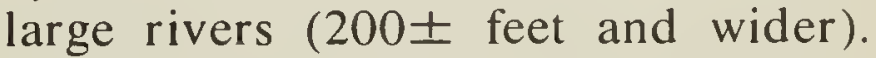
All other lakes and rivers were considered to be small. We also noted on which shore the nest was situated on islands more than $1 \mathrm{sq} \mathrm{mi}$ in area and along mainland shores. This is referred to as the orientation of the 


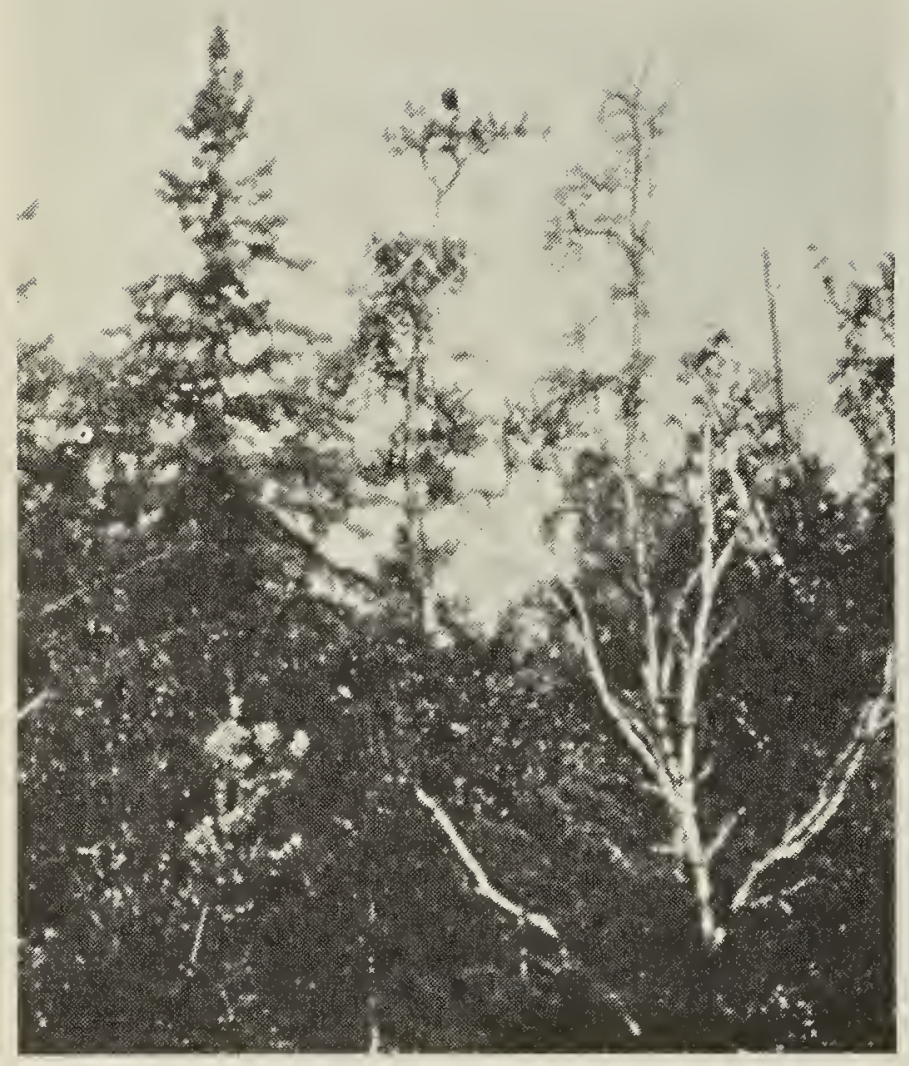

Fig. 1. An adult bald eagle in a tree perched just above its nest.

J. M. Gerrard

nest; a nest on an east shore was recorded as oriented west.

The location of each nest on Besnard Lake was plotted on forest inventory maps made from 1968 and 1969 aerial photographs. They show tree species and height and crown cover. By comparing forest types on the entire shore with the vegetation where eagles nested, we tried to determine what forest habitat the birds prefer.

Bald Eagles return to the boreal forest in April when the lakes are still frozen. The only feeding areas available to them are rapids and places around the lake where streams enter to create small areas of open water. These are important fish spawning areas and probably important eagle feeding spots. Because the presence of a spring food supply might influence the location of nests, we analyzed our nest data to see if successful nests were correlated with distance from a stream mouth. We restricted this analysis to streams that were actually open and used by spawning fish in spring.

All our measurements were made on $1: 250,000$ National Topographic System maps. Shoreline measurements for the 1974 survey were made by measuring the shoreline with dividers set at 1/2-mile spacing. All other map measurements were made with a map measurer with a $1 / 4$-inch wheel.

RESULTS. In our straight-line transect flown in 1974, we searched $47.8 \mathrm{sq} \mathrm{m}$ of shoreline habitat and $140.6 \mathrm{sq} \mathrm{mi} \mathrm{o}$ inland habitat. Eighteen Bald Eagl nests were found along the shorelin and no eagle nests were found in th inland habitat. The difference is highly significant and provides statistica confirmation of our earlier impressios that Bald Eagles in northern Saskat chewan strongly prefer shorelin habitat for their nests $\left(\chi^{2}=53, \mathrm{DF}=1\right.$ $\mathrm{P}<0.001$ ).

Four eagle nests were found in 26. sq $\mathrm{mi}$ of shoreline habitat on smal water bodies, whereas 14 eagle nest were found in $21.2 \mathrm{sq} \mathrm{mi}$ of shorelin habitat on large water bodies. The dif ference is statistically significant, an this finding confirms our impressio that Bald Eagles prefer to nest on larg lakes and rivers $\left(\chi^{2}=53, \mathrm{DF}=1\right.$ $\mathrm{P}<0.01)$.

In 1969,110 nests were found alon 589 miles of island shoreline and 14 nests were found along 2,480 miles $o$ mainland shore. The difference be tween island and mainland shoreline $i$ statistically significant and shows th preference for nest sites on island $\left(\chi^{\prime}{ }^{2}=91, \mathrm{DF}=1, \mathrm{P}<0.001\right)$

Eagle nests do not all face in th same direction nor are they oriented a random. Table 1 shows the directio faced by 136 nests found on the 196 


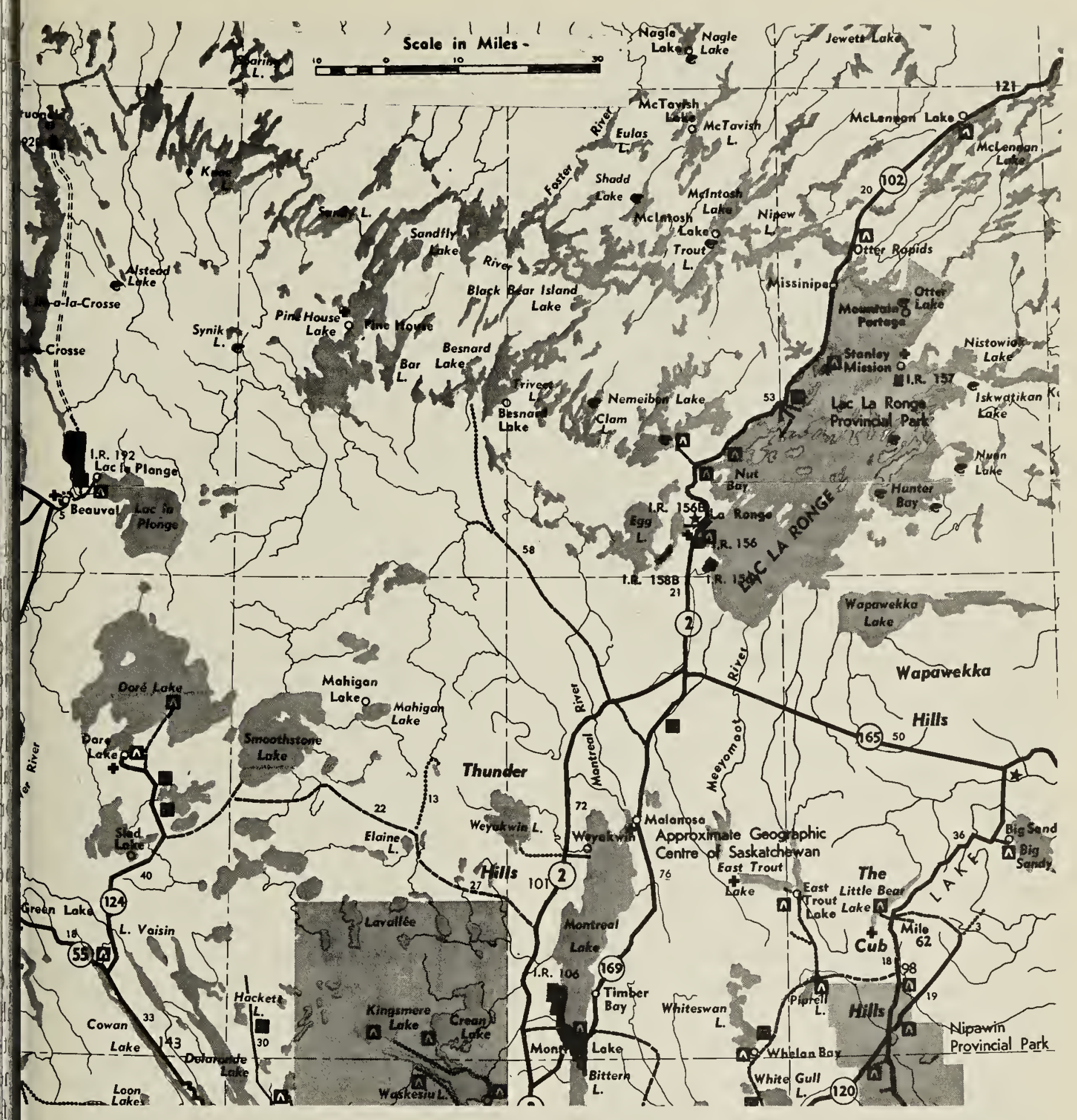

Besnard Lake and vicinity. The study area included Saskatchewan north of about $54^{\circ}$ lat. Ind into Manitoba. Note the northeast-southwest orientation of the Churchill River lakes ind tributaries.

urvey; this total omits all nests on slands less than $1 \mathrm{sq} \mathrm{mi}$ in area and hests on narrow peninsulas because hey could not readily be assigned a ingle direction. The largest number of lests $(48,35 \%)$, faced west. The listribution of nests is significantly different from random and suggests hat eagles prefer east and southeast hores of water bodies so that nests ace west and northwest $\left(\chi^{2}=81.7\right.$, $\mathrm{DF}=7, \mathrm{P}<0.001)$.
Two of our 1969 nests were on the tops of cliffs which rose from the water in a steep incline. The remaining 288 nests were in trees. Of these $156(54 \%)$ were in trembling aspen (Populus tremuloides ), $90(30 \%)$ were in spruce (Picea) and 39 (15\%) were in jack pine (Pinus banksiana). The other three nests were in balsam poplar (Populus balsamifera) and white birch (Betula papyrifera). Nests in the more northern part of the area surveyed tended to be 
in jack pine; in the central part most nests were in poplar and spruce, while nests in the south, in the Cumberland marshes, tended to be in dead aspen.

Finally, we used our long-term studies of eagles nesting at Besnard Lake to find out some characteristics of the forest vegetation that seems to influence eagles in locating their nests. Forest Service maps classed the vegetation into five types: mixedwood with softwood dominant, softwood, mixedwood with hardwood dominant, hardwood, and marsh or sparsely treed muskeg. The maps also classified forest stands into four height classes and into four classes of crown cover. We measured the number of shoreline miles around the lake in each forest type, height and cover class and determined the number of known nests in each category. The results show that eagles prefer softwood or forest with softwood dominant: $67 \%$ of 43 nests were in those two habitats (Table 2). Similarly, eagles do not like forests with dense crown cover, as $63 \%$ of the nests were in forests of 30-50 percent coverage (Table 3 ). Forest of more or less cover had significantly fewer nests per mile of shoreline $\left(\chi_{.}{ }^{2}=42.3\right.$, $\mathrm{DF}=1, \mathrm{P}<0.001)$.

Bald eagles showed a striking preference for tall trees (Table 4). Shoreline habitat with trees above 70 feet had 1.04 nests per mile, almost four times the density of any other
TABLE 1. Orientation of nests found on large islands and mainland shoreline in 1969.

\begin{tabular}{crr}
\hline $\begin{array}{c}\text { Direction } \\
\text { Nest Fuced }\end{array}$ & Nosts & \\
\hline N & 10 & 7 \\
NW & 18 & 13 \\
W & 48 & 35 \\
SW & 6 & 4 \\
S & 17 & 13 \\
SE & 12 & 9 \\
E & 21 & 15 \\
NE & 4 & 3 \\
\hline
\end{tabular}

category. This difference wa statistically significant $\left(\chi^{2}=34.1\right.$ $\mathrm{DF}=1, \mathrm{P}<0.001$ ).

The last factor analyzed was the im portance of open water in the spring o the location of successful eagle nests a determined by the presence or absenc of young in July. The 101 nest represent all nest records for 7 season work on the lake (Table 5). They shov a steady decrease in success of nest away from open spawning streams. Th difference in success between nests les than 2 miles from streams and thos farther away is significant $\left(\chi^{*}{ }^{2}=6.3\right.$ $\mathrm{DF}=1, \quad \mathrm{P}<0.05)$. Despite this however, there is no evidence thi nests tend to be built more closely $t$ such streams than elsewhere (Table 5

TABLE 2. Distribution of Bald Eagle nests by forest type on Besnard Lake, 1968-1974

\begin{tabular}{lcccc}
\hline Forest Type & \multicolumn{2}{c}{ Shoreline } & $\begin{array}{c}\text { No. of } \\
\text { nests }\end{array}$ & $\begin{array}{c}\text { Nests per mil } \\
\text { of shoreline }\end{array}$ \\
\cline { 4 - 5 } & Miles & $\%$ & & \\
$\begin{array}{l}\text { Mixedwood with } \\
\quad \text { softwood dominant }\end{array}$ & 37.9 & 15.4 & 13 & 0.34 \\
$\begin{array}{l}\text { Softwood } \\
\begin{array}{l}\text { Mixedwood with } \\
\quad \text { hardwood dominant }\end{array}\end{array}$ & 66.1 & 26.8 & 16 & 0.24 \\
$\begin{array}{l}\text { Hardwood } \\
\begin{array}{l}\text { Marsh or sparsely } \\
\text { treed muskeg }\end{array}\end{array}$ & 36.9 & 15.0 & 6 & 0.16 \\
\hline
\end{tabular}


piscussion. Bald Eagles in the boreal orest of Saskatchewan and Manitoba -eem to prefer to nest within 220 yards if large lakes and rivers. They prefer o nest on islands rather than on the nainland and prefer to face their nests owards the west and northwest, i.e., hey tend to nest on east and southeast hores. For nest trees they prefer aspen ind strongly prefer trees more than 70 eet tall in a softwood stand of moderate to low crown cover. Finally, hests within 2 miles of spawning treams that have open water in the pring show significantly greater sucess than those farther away.

Bald Eagles prefer shoreline habitat or nest sites in other areas also, ${ }^{1} 510$ ut a notable difference is evident in he more populated areas of Wisconsin and Minnesota where eagle nests are requently located more than $1 / 2$ mile rom water -36 percent of nests in he Bena district of Minnesota ${ }^{7}$ (C. findelar personal communication). It is ossible, therefore, that increased uman presence on the lakes of norhern Saskatchewan and Manitoba vith cottages and other developments long the shoreline could lead to agles choosing sites farther from open vater.

Why eagles prefer large rather than mall bodies of water for nesting is not s clear. Factors such as the larger ishing area, taller nest trees, and reater productivity while young are $n$ the nest are probably important. he presence of long shoreline upIrafts which facilitate travel to and rom fishing areas may also be imporant. A considerable portion of eagle rests on small lakes were within 2 niles of large lakes. ${ }^{13}$ The presence of he large lake may be the factor inlucing this as these eagles could acually use the large lake with its resumed advantages just as a resident agle.

There is a wide variation in the tree pecies Bald Eagles choose for nest sites across North America. In Saskatchewan and Manitoba trembling aspen is most frequently used. In the Tongass National Forest of southeast Alaska, Sitka spruce (Picea sitchensis) is used most frequently for nests. ${ }^{2}{ }^{9}$ On San Juan Island, Washington, Douglas fir (Pseudotsuga menziesii) is preferred;10 in northern Minnesota the birds prefer red pine (Pinus resinosa) and white pine (Pinus strobus), ${ }^{7}$ and near Lake Erie they formerly preferred sycamore (Platanus occidentalis) and shellbark hickory (Carya ovata). ${ }^{6}$ It is apparent from the variety of trees used that Bald Eagles react to the structure of the tree and the forest community rather than to the species itself.

Our observations at Besnard Lake show that in anything more than a light wind, eagles land on the nest facing into the wind; therefore, a nest needs to be approachable from several directions. This factor may explain their preference for tall, relatively exposed trees in open forest. ${ }^{810}$

The preference of eagles for nesting on islands rather than mainland is difficult to explain. The usual explanation for island nesting in waterfowl is that it protects them from predators, particularly mammals. This is probably not a factor in nest site selection by eagles. One possibility, suggested above, is the open, exposed site provided by islands; this allows ready access to the nest from many directions, depending on wind direction. Another possibility is that islands, being protected from the frequent lightning-caused fires of the boreal forest, usually have mature stands which provide the eagles with the tall trees they prefer. Islands are also close to fishing areas in all directions.

The direction that a nest faces is probably significant, as the eagles show definite preferences for some directions over others. However, they do not have equal opportunity to 


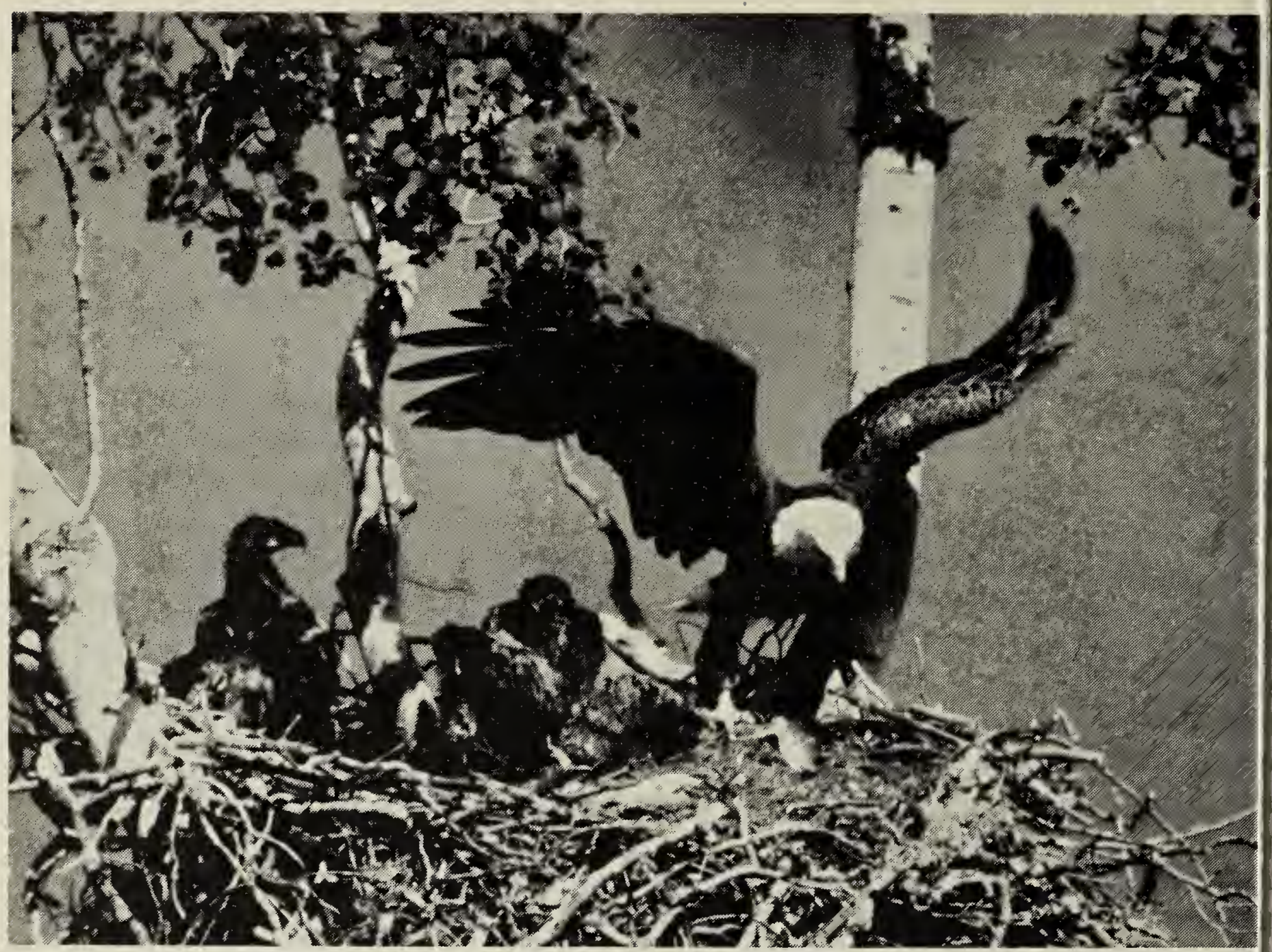

Fig. 2. A bald eagle landing on its nest with a fish.

J. M. Gerrard

TABLE 3. Distribution of Bald Eagle nests by forest crown cover density on Besnard Lake, 1968-1974.

\begin{tabular}{|c|c|c|c|c|}
\hline $\begin{array}{c}\text { Percent crown } \\
\text { cover }\end{array}$ & Miles & $\%$ & $\begin{array}{l}\text { No. of } \\
\text { nests }\end{array}$ & $\begin{array}{l}\text { Nests per mile } \\
\text { of shoreline }\end{array}$ \\
\hline Less than $30 \%$ & 37.4 & 15.1 & 0 & 0.0 \\
\hline $30-50 \%$ & 53.1 & 21.4 & 27 & 0.51 \\
\hline $50-70 \%$ & 111.4 & 45.0 & 14 & 0.13 \\
\hline More than $70 \%$ & 45.7 & 18.5 & 2 & 0.04 \\
\hline
\end{tabular}

TABLE 4. Relationship between tree height and nest site of Bald Eagles on Besnard Lake 1968-1974.

\begin{tabular}{lrrrr}
\hline Tree height & Miles & $\begin{array}{c}\text { Shoreline } \\
\text { Marsh of sparsely }\end{array}$ & $\begin{array}{r}\text { No. of } \\
\text { nests }\end{array}$ & $\begin{array}{r}\text { Nests per mile } \\
\text { of shoreline }\end{array}$ \\
$\quad$ treed muskeg & & & & \\
Less than 30 feet & 34.1 & 13.8 & 0 & 0.0 \\
$30-50$ feet & 57.4 & 23.3 & 1 & 0.02 \\
$50-70$ feet & 52.0 & 21.1 & 8 & 0.15 \\
Above 70 feet & 95.2 & 38.6 & 26 & 0.27 \\
\hline
\end{tabular}


hoose any direction. Glacial scouring $f$ the precambrian shield in northern askatchewan is oriented from northast to southwest and lake basins end to be similarly oriented. Hence pere is very little northeast or southest shoreline and a disproportionate mount of northwest- and southeasticing shoreline. This is evident in the lap, particularly for the lakes which hake up the Churchill River. Yet if we ompare the number of nests on east nd southeast-facing shoreline with est and northwest-facing shoreline, vice as many nests are on the latter as $n$ the former (66 vs. 33, Table 1). The igh proportion of nests along east hores may be because winds create ivourable soaring conditions along a est-facing shoreline, ${ }^{4}$ or because the ast shore is more sheltered from the redominant east wind during inubation. It is also possible that exosure to the warmth of the south and est sun may be important in the pring as well.

UMMARY. Bald Eagles in northern askatchewan and Manitoba show a lose association with shoreline abitat. Nests are more frequently pund along the shores of large lakes nd rivers than along small waters. hey are not found inland from water odies. Island shoreline is used for ests more frequently than mainland horeline. Nests on large islands and he mainland showed a significant ten- dency to be situated on the east shores of water bodies. An analysis of the utilization of shoreline habitat for nests by Bald Eagles on Besnard Lake, Saskatchewan, revealed a preference for tall, relatively open mixedwood forest with softwood dominant. Nests within 2 miles of small streams entering the lake showed a higher breeding success rate than more distant nests, although the presence of the streams did not appear to influence the location of nests.

ACKNOWLEDGEMENTS. Our study has been supported financially by the Canadian Wildlife Service, the Institute of Northern Studies at the University of Saskatchewan, the Saskatchewan Department of Natural Resources, the Manitoba Museum of Man and Nature in Winnipeg, the Churchill River Wildlife Study Sector, Parks Canada, and by the National Research Council of Canada through its grant to W. J. Maher. Naomi Gerrard helped in the preparation of the manuscript. Mr. John Hastings of Besnard Lake provided information on streams that are open when Bald Eagles arrive in April.

BROLEY, J. M. 1952. The eagle man. Pellegrine and Cudahy, New York, 210 p.

${ }^{2}$ CORR, P. O. 1969. Bald eagle nest ecology Federal Aid in Fish and Wildlife Restoration. Alaska W-17-R-1, Work Plan B, Job 9. Small

ABLE 5. Nest success and proximity to spawning streams open in spring on Besnard Lake, 1968-1974.

\begin{tabular}{|lcccc}
\hline \multicolumn{5}{c}{ Active Nests } \\
\hline $\begin{array}{l}\text { Miles from } \\
\text { stream }\end{array}$ & Total & With young & Empty & $\begin{array}{c}\text { \% with } \\
\text { young }\end{array}$ \\
\hline ess than 1 & 16 & 14 & 2 & 87 \\
-1.9 & 24 & 17 & 7 & 71 \\
-2.9 & 18 & 8 & 10 & 44 \\
-3.9 & 32 & 17 & 15 & 53 \\
-4.9 & 11 & 5 & 6 & 45 \\
\hline
\end{tabular}


game, waterfowl and furbearer investigation. Unpublished Report.

"GERRARD, J. M., and D. W. A. WHITFIELD. 1967. Bald Eagle banding in northern Saskatchewan. Blue Jay 25:177-183.

${ }^{4}$ GER RARD, J. M. 1973. Eagle census experiences in Canada. In notes on a Bald Eagle nest survey workshop. Ed. C. R. Madsen, U. S. Dept. Interior.

'HENSEL, R. J., and W. A. TROYER. 1964. Nesting studies of the Bald Eagle in Alaska. Canada 66:282-286.

${ }^{6}$ HERRICK, F. H. 1934. The American eagle. New York. D. Appelton-Century Co., New York, N.Y., 267 p.

JJUENEMANN, B. G. 1973. Habitat evaluation of selected Bald Eagle nest sites on the Chippewa National Forest. M.Sc. Thesis. Univ. Minnesota, Minneapolis.

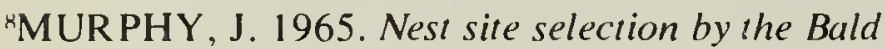
Eagle in Yellowstone National Park. Utah Academy of Sciences, Arts and Letters (Provo) Proc. Vol. 42, Part 2:261-264.
"POULIN, E. M. 1968. Bald Eagle nest ecology. Federal Aid in Fish and Wildlife Restoration. Alaska W-13-R-3, Work Plan B, Job 9. Small game and furbearer investigations. Unpublished report.

"RETFALVI, L. I. 1965. Breeding behavior and feeding habits of the Bald Eagle (Haliaetus leucocephalus L.) on San Juan Island, Washington. M. Forestry Thesis. Univ. British Columbia, Vancouver. 193 p.

"RICHARDS, J. H., and K. I. FUNG (Editors) 1969. Atlas of Saskatchewan. Univ. Saskat chewan, Saskatoon. 236 p.

${ }^{12}$ ROWE, J. S. 1972. Forest regions of Canada Canadian Forestry Service, Ottawa. 172 p.

1:3HITFIELD, D. W. A., J. M. GERRARD, W J. MAHER, and D. W. DAVIS. 1974. Balk Eagle nesting habitat, density, and reproduction in Central Saskatchewan and Manitoba. Can. Field Nat. 88:399-407.

\title{
FIRST RECORDS OF THE ORCHARD ORIOLE IN SASKATCHEWAN
}

\author{
by E. MANLEY CALLIN*
}

On three dates from June 19 to June 28, 1974, I stopped briefly at the P.F.R.A. dam over the river at the northern edge of the town of Fort Qu'Appelle and in an adjacent, heavily wooded area I heard a lively warble similar to the Purple Finch. The bird could not be seen from the perimeter of the woods and it was singing from a residential area. On June 29 I asked the residents, Constable John Lloyd and his wife, for permission to enter

*Fort Qu'Appelle, Saskatchewan the area for the purpose of observin and recording. They were mos obliging and during the next hour taped about 35 songs but the bird w? extremely shy and not once could I ge a glimpse of it.

On June 30 Jack Lowe of For Qu'Appelle and on July 1 Fran Brazier of Regina assisted in th search for identity of the elusive bir which sang regularly but remaine hidden in the upper portion of a ver high spruce tree. During these tw days more songs and calls were reco 